Jurnal e-GiGi (eG), Volume 2, Nomor 2, Juli-Desember 2014

\title{
STATUS KEBERSIHAN GIGI DAN MULUT PASIEN POLIKLINIK GIGI PUSKESMAS PANIKI BAWAH MANADO
}

\author{
${ }^{1}$ Daul R Tuhuteru \\ ${ }^{2}$ B. S Lampus \\ ${ }^{2}$ Vonny N.S Wowor
}

\author{
${ }^{1}$ Kandidat Skripsi Program Studi Kedoteran Gigi Fakultas Kedokteran \\ Universitas Sam Ratulangi Manado \\ ${ }^{2}$ Program Studi Kedokteran Gigi Fakultas Kedokteran Universitas Sam Ratulangi Manado
}

\begin{abstract}
Abstrak: Kebersihan gigi danmulut yang baik berdampak pada kesehatan mulut, sebaliknya kebersihan mulut yang kurang terjaga dapat menyebabkan berbagai macam penyakit pada rongga mulut sebagai akibat akumulasi debris dan kalkulus. Tujuan penelitian ini untuk mengetahui status kebersihan gigi dan mulut pasien Poliklinik Gigi Puskesmas Paniki Bawah Manado. Penelitian ini bersifat deskriptif menggunakan pendekatan cross sectional studydengan populasi terjangkau pasien pengunjung poliklinik gigi yang berusia 20-44 tahun dan jumlah sampel 55. Pengambilan sampel menggunakan purposive sampling method. Hasil penelitian menunjukkan bahwa berdasarkan jenis kelamin indeks debris tererndah pada perempuan sebesar 1,1 dan indeks kalkulus terrendah juga pada perempuan sebesar 1,2; berdasarkan kelompok usia, indeks debris terrendah pada kelompok usia 26-35 tahun sebesar 1,1; indeks kalkulus terrendah pada kelompok usia 26-35 tahun dan 36-44 tahun sebesar 1,3; indeks kebersihan mulut (OHI-S) terrendah pada perempuan sebesar 2,3; berdasarkan kelompok usia, indeks kebersihan mulut (OHI-S) terrendah berada pada usia 26-35 tahun sebesar 2,4. Indeks kebersihan mulut rata-rata keseluruhan adalah 2,5. Sebagai kesimpulan bahwa indeks debris dan indeks kalkulus terbaik pada pasien berjenis kelamin perempuan sedangkan berdasarkan kelompok usia, indeks debris terbaik pada pada kelompok usia 26-35 tahun; dan indeks kalkulus terbaik pada pasien kelompok usia 26-35 tahun dan kelompok usia 36-44 tahun. Status kebersihan mulut (OHI-S) rata-rata pasien baik laki-laki maupun perempuan termasuk dalam kategori sedang, sedangkan status kebersihan mulut (OHI-S) rata-rata berdasarkan kelompok usia semuanya juga termasuk kategori sedang. Saran penulis, pemerintah hendaknya lebih memerhatikan derajat kesehatan gigi dan mulut masyarakat, melalui berbagai program peningkatan pelayanan kesehatan gigi dan mulut di puskesmas.
\end{abstract}

Kata kunci: Status Kebersihan Mulut, Indeks Kebersihan Mulut, Indeks Debris, IndeksKalkulus

Kebersihan gigi dan mulut yang baik berdampak pada kesehatan gigi dan mulut, sebaliknya kebersihan mulut yang kurang terjaga dapat menyebabkan berbagai macam penyakit pada rongga mulut sebagai akibat timbulnya debris dan karang gigi atau kalkulus $^{1}$. Kalkulus timbul pada daerahdaerah gigi yang sulit dibersihkan, di mana kalkulus ini menjadi tempat melekatnya kuman-kuman di dalam mulut. Akumulasi debris yang banyak mengandung berbagai macam bakteri serta kuman pada kalkulus dapat menyebabkan berbagai penyakit periodontal, seperti radang gusi (gingivitis), radang jaringan penyangga gigi (periodontitis) dan gigi goyang. ${ }^{2,3}$ Salah satu tujuan Oral Health 2020 yang telah disepakati World HealthOrganisation (WHO), dan Federation Dentaire Internationale (FDI) untuk penyakit periodontal, yaitu mengurangi kehilangan gigi akibat penyakit periodontal pada usia 18 tahun, 35-44 tahun, dan 65-74 tahun, terutama untuk kasus kebersihan mulut yang buruk. ${ }^{4}$ Cara yang 
terbaik dalam mencegah dan menyembuhkan penyakit periodontal adalah dengan kontrol debris. Penyakit periodontal merupakan masalah kesehatan yang sudah mendunia. Berdasarkan Survei Kesehatan Rumah Tangga-Survei Kesehatan Nasional Tahun 2010 penyakit periodontal menduduki urutan kedua dengan jumlah penderita 42,8\% penduduk Indonesia. ${ }^{5}$ Prevalensi penyakit periodontal meningkat seiring dengan pertambahan usia. Berdasarkan survei yang dilakukan Nasional Institute of Dental Research (NIDR) di Indonesia, penyakit periodontal menduduki urutan kedua utama yang masih merupakan masalah di masyarakat. Di Indonesia penyakit periodontal merupakan penyakit gigi dan mulut yang terbanyak diderita masyarakat (70\%). Kalkulus sebagai salah satu penyebabnya dijumpai pada 46,2\% penduduk. Prevalensi kalkulus pada penduduk di pedesaan lebih tinggi yaitu sebesar $48,9 \%$, sedangkan di perkotaan sebesar $42,5 \%{ }^{5}$

Kontrol debris adalah pembersihan dan pengangkatan debris untuk mencegah terjadinya akumulasi debris pada permukaan gigi dan gingiva. Kontrol debris secara mekanis merupakan cara terbaik untuk menghilangkan debris seperti penggunaan sikat gigi, dental floss dan tusuk gigi. Selain itu, pembersihan debris secara mekanis disebut dengan oral fisioterapi. Oral fisioterapi adalah membersihkan gigi dan gingiva dari sisa makanan, material alba, debris, dan melakukan pemijatan gingiva. ${ }^{5}$

Kebersihan mulut dapat ditentukan lewat pengukuran status kebersihan mulut. Pengukuran status kebersihan mulut yang umum digunakan yakni dengan menggunakan Oral Hygiene Indeks Simplified (OHI-S) dari Green dan Vermillion. Penentuan indeks dilakukan dengan terlebih dahulu mengukur indeks debris dan indeks kalkulus. ${ }^{6}$

Puskesmas Paniki Bawah Manado merupakan puskesmas yang terletak di ujung Utara Kota Manado. Puskesmas tersebut relatif jauh dari rumah sakit. Saat penulis melakukan praktek belajar lapangan, ditemukan banyak masalah kesehatan gigi dan mulut terlebih khusus berkaitan dengan penyakit periodontal. Berdasarkan survei awal yang dilakukan penulis, diperoleh data bahwa cukup banyak pasien yang berkunjung dari bulan Januari hingga Juni 2013 di Poliklinik gigi Puskesmas Paniki Bawah menderita gangguan periodontal. Gangguan ini meliputi gingivitis, mobiliti gigi, dan penyakit periodontal. Informasi lainnya yang diperoleh juga menunjukkan bahwa pasien yang berkunjung ke Puskesmas tersebut jarang mendapat sosialisasi tentang kesehatan gigi dan mulut serta bagaimana cara menjaga kebersihan gigi dan mulut dengan baik. Kondisi inilah yang mendorong penulis untuk melakukan penelitian untuk memperoleh gambaran tentang status kebersihan mulut pasien di Poliklinik Gigi Puskesmas Paniki Bawah Manado.

\section{BAHAN DAN METODE}

Penelitian ini dilaksanakan di Poliklinik Gigi Puskesmas Paniki Bawah Manado pada bulan Februari - April 2014 pada pasien yang berumur 20-44 tahun yang berkunjung dan terdaftar di Poliklinik Gigi Puskesmas Paniki Bawah Manado sebanyak 55 sampel. Pada penelitian ini sampel diambil dengan menggunakan teknik purposive sampling, yakni peneliti melakukan pemeriksaan pada pasien yang berkunjung di Poliklinik Gigi Puskesmas Paniki Bawah Manado.

Pengambilan data yaitu data primer berupa nama, usia dan jenis kelamin dan diperoleh langsung dari responden saat berkunjung. Data pemeriksaan status kebersihan gigi dan mulut diperoleh saat masingmasing responden diperiksa di Poliklinik Gigi Puskesmas Paniki Bawah Manado.

Data diolah dengan menggunakan program komputer Microsoft Office Excel 2010 dan dianalisis secara univariat untuk mendapatkan gambaran distribusi variabel status kebersihan gigi dan mulut kemudian ditampilkan dalam bentuk tabel lalu diinterprestasikan.

\section{HASIL PENELITIAN}

Karakteristik subjek penelitian dibedakan atas jenis kelamin dan kelompok usia. Tabel 1 memperlihatkan distribusi subjek penelitian berdasarkan jenis kelamin. 
Tuhuteru, Lampus, Wowor; Status Kebersihan Gigi dan Mulut Pasien...

Tabel 1. Distribusi subjek penelitian berdasarkan jenis kelamin.

\begin{tabular}{ccc}
\hline Jenis kelamin & $\mathbf{n}$ & $\mathbf{\%}$ \\
\hline Laki-laki & 17 & 30,9 \\
Perempuan & 38 & 69,1 \\
\hline Jumlah & 55 & 100 \\
\hline
\end{tabular}

Tabel 2. Distribusi subjek penelitian berdasarkan kelompok usia.

\begin{tabular}{ccc}
\hline Usia & n & \% \\
\hline 20-25 tahun & 7 & 12,7 \\
26-35 tahun & 27 & 49,1 \\
$36-44$ tahun & 21 & 38,2 \\
\hline Jumlah & 55 & 100
\end{tabular}

Tabel 3. Distribusi frekuensi Indeks Debris dan Indeks Kalkulus subjek penelitian berdasarkan jenis kelamin.

\begin{tabular}{lcccc}
\hline $\begin{array}{c}\text { Jenis } \\
\text { kelamin }\end{array}$ & n & $\%$ & $\begin{array}{c}\text { Indeks } \\
\text { debris } \\
\text { (DI) }\end{array}$ & $\begin{array}{c}\text { Indeks } \\
\text { kalkulus } \\
\text { (CI) }\end{array}$ \\
\hline Laki-laki & 17 & 30,9 & 1,3 & 1,5 \\
Perempuan & 38 & 69,1 & 1,1 & 1,2 \\
\hline Jumlah & 55 & \multicolumn{2}{c}{100} &
\end{tabular}

Tabel 4. Distribusi frekuensi Indeks Debris dan Indeks Kalkulus subjek penelitian berdasarkan kelompok usia.

\begin{tabular}{ccccc}
\hline $\begin{array}{c}\text { kelompok } \\
\text { Usia }\end{array}$ & $\mathbf{n}$ & $\mathbf{\%}$ & $\begin{array}{c}\text { Indeks } \\
\text { Debris } \\
\text { (DI) }\end{array}$ & $\begin{array}{c}\text { Indeks } \\
\text { Kalkulus } \\
\text { (CI) }\end{array}$ \\
\hline $\begin{array}{c}20-25 \\
\text { tahun }\end{array}$ & 7 & 12,7 & 1,3 & 1,4 \\
\hline $\begin{array}{c}26-35 \\
\text { tahun }\end{array}$ & 27 & 49,1 & 1,1 & 1,3 \\
\hline $\begin{array}{c}36-44 \\
\text { tahun }\end{array}$ & 21 & 38,2 & 1,3 & 1,3 \\
\hline
\end{tabular}

Tabel 5. Distribusi Indeks Kebersihan Mulut subjek penelitian berdasarkan jenis kelamin.

\begin{tabular}{lcc}
\hline \multicolumn{1}{c}{$\begin{array}{c}\text { Jenis } \\
\text { Kelamin }\end{array}$} & $\begin{array}{c}\text { Indeks } \\
\text { Kebersihan } \\
\text { Mulut (OHI-S) }\end{array}$ & $\begin{array}{c}\text { Status } \\
\text { OHI-S }\end{array}$ \\
\hline Laki-Laki & 2,8 & Sedang \\
Perempuan & 2,3 & Sedang \\
\hline Indeks rata- & 2,5 & Sedang \\
rata & & \\
\hline
\end{tabular}

Tabel 6. Distribusi Indeks Kebersihan Mulut subjek penelitian berdasarkan kelompok usia

\begin{tabular}{lcccc}
\hline $\begin{array}{c}\text { Kelompok } \\
\text { Usia }\end{array}$ & $\mathbf{n}$ & $\mathbf{\%}$ & $\begin{array}{c}\text { Index } \\
\text { kebersihan } \\
\text { mulut } \\
\text { (OHI-S) }\end{array}$ & $\begin{array}{c}\text { Status } \\
\text { OHI-S }\end{array}$ \\
\hline $20-25$ & 7 & 12,7 & 2,7 & Sedang \\
tahun & & & & Sedang \\
$26-35$ & 27 & 49,1 & 2,4 & Sedang \\
$\begin{array}{c}\text { tahun } \\
36-44 \\
\text { tahun }\end{array}$ & 21 & 38,2 & 2,6 & Sedang \\
\hline \multicolumn{5}{r}{} \\
\hline
\end{tabular}

\section{BAHASAN}

Hasil yang diperoleh menunjukan subjek penelitian berdasarkan jenis kelamin yakni pada laki-laki sebanyak 17 orang (30,9\%), sedangkan pada prempuan 38 orang $(69,1 \%)$.

Hasil yang diperoleh berdasarkan usia yakni pada kelompok usia 20-25 tahun sebanyak 7 orang (12,7\%), kelompok usia 26-35 tahun sebanyak 27 orang (49,1\%), dan kelompok usia 36-44 tahun sebanyak 21 orang (38,2\%).

Hasil pemeriksaan Indeks Debris pada 55 subjek penelitian berdasarkan jenis kelamin. Hasilnya menunjukkan bahwa subyek penelitian yang berjenis kelamin laki-laki sebanyak 17 orang (30,9\%), memiliki Indeks Debris sebesar 1,3 dan Indeks Kalkulus sebesar 1,5. Subyek penelitian berjenis kelamin perempuan sebanyak 38 orang $(69,1 \%)$ memiliki Indeks Debris 1,1 dan Indeks kalkulus 1,2.

Hasil pemeriksaan indeks debris, indeks kalkulus pada 55 subjek penelitian berdasarkan kelompok usia. Hasilnya menunjukkan bahwa subjek penelitian kelompok usia 20-25 tahun sebanyak 7 orang (12,7\%) memiliki indeks debris 1,3 dan indeks kalkulus sebesar 1,4. Subjek penelitian dengan kelompok usia 26-35 tahun sebanyak 27 orang (49,1\%) memliki indeks debris sebesar 1,1 dan indeks kalkulus sebesar 1,3. Subjek penelitian dengan kelompok usia 36-44 tahun sebanyak 21 orang $(38,2 \%)$ memiliki indeks debris sebesar 1,3 ; indeks kalkulus sebesar 1,3. Sedangkan skor indeks rata-rata dari 
kelompok usia 20-44 tahun secara keseluruhan memiliki indeks debris sebesar 1,2 ; indeks rata-rata kalkulus sebesar 1,3.

Hasil penelitian pada Tabel 5 menunjukkan bahwa Indeks Kebersihan Mulut pada laki-laki rata-rata 2,8 termasuk kategori sedang, pada perempuan rata-rata 2,3 termasuk kategori sedang dan indeks rata-rata keseluruhan 2,5 termasuk kategori sedang. Penelitian ini tidak jauh berbeda dengan penelitian yang dilakukan oleh Wowor, E.V pada siswa SMAN 1 Manado dimana penelitian tersebut menunjukkan indeks keberihan mulut rata-rata pada lakilaki sebesar 1,6 termasuk kategori sedang serta pada perempuan 1,5 termasuk kategori sedang.Menurut Wowor perempuan lebih baik dalam perilaku menjaga kebersihan gigi dan mulut dibandingkan laki-laki, hal ini disebabkan perempuan lebih mementingkan dan memiliki kesadaran yang tinggi akan estetik dan pemeliharaan kebersihan giginya sehingga akan lebih rajin untuk menyikat gigi dibandingkan laki-laki. ${ }^{7}$

Hasil penelitian di atas menujukkan bahwa indeks kebersihan mulut rata-rata kelompok usia 20-25 tahun sebesar 2,7 termasuk kategori sedang; indeks kebersihan mulut rata-rata kelompok usia 26-35 tahun sebesar 2,4 termasuk kategori sedang; indeks kebersihan mulut rata-rata kelompok uisa 36-44 tahun sebesar 2,4 termasuk kategori sedang. Indeks rata-rata keseluruhan yakni sebesar 2,5 termasuk kategori sedang. Penelitian ini tidak jauh berbeda dengan penelitian dilakukan oleh Tjahja I pada kelompok usia 20-45 tahun di kotamadya Bandung dan kabupaten bandung dimana hasil nilai OHI-S yang diperoleh rata-rata berkisarantara 1,95-1,98 dan termasuk kategori sedang. Tjahja I menyatakan, bahwa pengetahuan dan sikap individu yang baik akan memberikan pengaruh yang cukup besar terhadap pemeliharaan kesehatan gigi dan mulut. ${ }^{8}$ Hasil pada kelompok usia 20-25 tahun indeks kebersihan mulutnya sedikit lebih tinggi dari kelompok usia lainnya, yang menggambarkan bahwa kebersihan mulutnya lebih rendah dibandingkan kelompok usia lainnya walaupun kategori hasilnya tidak berbeda. Penulis berpendapat bahwa hal ini mungkin disebabkan karena pada kelompok usia ini responden dinilai belum memiliki kesadaran penuh menyangkut kesehatannya termasuk kesehatan giginya. Menurut Boediharjo, bahwa yang terpenting dalam upaya menjaga kebersihan mulut adalah faktor kesadaran dan perilaku pemeliharaan hygiene mulut masing-masing. Sepenuhnya tergantung dari pengetahuan, pemahaman, kesadaran serta kemauan dari responden untuk menjaga kesehatan gigi dan mulutnya. Untuk itu cara yang paling mudah dan umum dilakukan adalah dengan cara menyikat gigi secara teratur dan benar karena hal tersebut merupakan usaha yang dapat dilakukan secara peribadi. ${ }^{9}$

\section{SIMPULAN}

Sebagai kesimpulan bahwa indeks debris dan indeks kalkulus terbaik pada pasien berjenis kelamin perempuan sedangkan berdasarkan kelompok usia, indeks debris terbaik pada pada kelompok usia 26-35 tahun; dan indeks kalkulus terbaik pada pasien kelompok usia 26-35 tahun dan kelompok usia 36-44 tahun. Status kebersihan mulut (OHI-S) rata-rata pasien baik laki-laki maupun perempuan termasuk dalam kategori sedang, sedangkan status kebersihan mulut (OHI-S) rata-rata berdasarkan kelompok usia semuanya juga termasuk kategori sedang.

\section{SARAN}

Saran penulis, pemerintah hendaknya lebih memerhatikan derajat kesehatan gigi dan mulut masyarakat, melalui berbagai program peningkatan pelayanan kesehatan gigi dan mulut di puskesmas.

\section{DAFTAR PUSTAKA}

1. Rahmadhani, A. G. Kesehatan Gigi dan Mulut. Bukune, Jakarta, 2010.

2. Budiharto. Pengantar Ilmu Perilaku Kesehatan dan Pendidikan Kesehatan Gigi. Penerbit Galaxy, Jakarta. 1998. 
Tuhuteru, Lampus, Wowor; Status Kebersihan Gigi dan Mulut Pasien...

3. Hobdell M. Global Goals For Oral Health 2020. International Dental Journal. 2003;53, 285-88.

4. Carranza Fa. Glickman,s Clinical Periodonlogy 8th Ed. Philadelphia saunders. 1996, p.57-79, 218-232.

5. Daliemunthe, S. I. Periodonsia. Universitas Sumatra Utara, Medan. 2005.

6. Mulyawati Y. kalkulus dan cara mengatasinya, Direktorat Gizi Masyarakat. [serial online] 2008 [cited 20 April 2013]. Available from URL http://www.kesehatangigi.blogspot.com /2008/01/karanggigi,accesed,Jakarta, Peb $11^{\text {th }} 2008$.

7. Wowor E.V. Skripsi Hubungan Antara Status Kebersihan Mulut Dengan Karies Pada Siswa Sekolah Menengah Atas Negeri 1 Manado. Fakultas Kedokteran. Universitas Sam Ratulangi; 2013.

8. Tjahja I dan Lely M, A. Hubungan Kebersihan Gigi dan Mulut Dengan Pengetahuan Dan Sikap Di Beberapa Puskesmas Di Propinsi Jawa Barat. Media Litbang Kesehatan. 2005. Hal 15-4

9. Boediharjo. jurnal Kedokteran gigi Indonesia. Fakultas kedokteran Gigi. Universitas Indonesia. Jakarta ; 2005 